\title{
Stem growth of woody species at the Nkuhlu exclosures, Kruger National Park: 2006-2010
}

\author{
Author: \\ Peter F. Scogings ${ }^{1}$ \\ Affiliation: \\ ${ }^{1}$ Department of Agriculture, \\ University of Zululand, \\ South Africa \\ Correspondence to: \\ Peter Scogings \\ Email: \\ pscoging@pan.uzulu.ac.za \\ Postal address: \\ Private Bag X1001, \\ KwaDlangezwa 3886, \\ South Africa \\ Dates: \\ Received: 04 Nov. 2010 \\ Accepted: 07 Apr. 2011 \\ Published: 08 July 2011 \\ How to cite this article: \\ Scogings, P.F., 2011, 'Stem \\ growth of woody species \\ at the Nkuhlu exclosures, \\ Kruger National Park: 2006- \\ 2010', Koedoe 53(1), Art. \\ \#1035, 8 pages. doi:10.4102/ \\ koedoe.v53i1.1035
}

(c) 2011. The Authors. Licensee: AOSIS OpenJournals. This work is licensed under the Creative Commons Attribution License.
An important aspect of managing African conservation areas involves understanding how large herbivores affect woody plant growth. Yet, data on growth rates of woody species in savannas are scarce, despite its critical importance for developing models to guide ecosystem management. What effect do browsing and season have on woody stem growth? Assuming no growth happens in the dry season, browsing should reduce stem growth in the wet season only. Secondly, do functional species groups differ in stem growth? For example, assuming fine-leaved, spiny species' growth is not compromised by carbon-based chemical defences, they should grow faster than broad-leaved, chemically defended species. Dendrometers were fixed at $20 \mathrm{~cm}$ in height on the main stems of 244 random plants of six woody species in three plots (all large herbivores excluded, partial exclusion, and control) and observed from late 2006 to early 2010. Average monthly increment (AMI) per dendrometer and season (dry, wet) was calculated and the interaction between plot and season tested per species, controlling for initial stem girth. AMIs of Combretum apiculatum, Dichrostachys cinerea and Grewia flavescens were zero in the dry season, whilst those of Acacia exuvialis, Acacia grandicornuta and Euclea divinorum were either positive or negative in the dry season. Wet-season AMI of $D$. cinerea and dry-season AMI of G. flavescens tended to be reduced by browser exclusion. Net AMI (sum of the seasonal AMIs) was tested per species, but results suggested that only D. cinerea tended to be affected by browser exclusion. The results also suggested that stem radial growth of some fast-growing species is more prone to reduction by browser exclusion than the growth of other species, potentially reducing their competitiveness and increasing their risk of extirpation. Finally, the usefulness of grouping woody species into simple functional groups (e.g. fineleaved vs. broad-leaved) for ecosystem management purposes in savannas requires further consideration.

Conservation implications: Growth rates of woody plants are important parameters in savanna models, but data are scarce. Monitoring dendrometers in manipulative situations over several years can help fill that gap. Results of such studies can be used to identify species prone to high risk of extirpation.

\section{Introduction}

A major component of current research in savannas concerns the effects of large herbivores (especially elephants) on woody vegetation, with the ultimate objective being the development of improved management policies (Levick \& Rogers 2008). Growth rates of woody plants are important parameters in models developed for the purposes of understanding savanna ecosystems and ultimately guiding the management of extensive conservation areas comprising heterogeneous savanna landscapes and mega-herbivores, but critical data on growth are scarce (Baxter \& Getz 2005). Apart from the dearth of studies of woody plant growth rates under the influence of elephants, most studies of responses of woody plants to browsing in savannas have only recorded shoot growth, which generally responds positively to long-term severe browsing (Engdahl 2008; Fornara \& Du Toit 2007; Hrabar, Hattas \& Du Toit 2009; Makhabu, Skarpe \& Hytteborn 2006; Riginos \& Young 2007). Numerous short-term clipping studies have revealed the same trend (Bergström, Skarpe \& Danell 2000; Fonara \& Du Toit 2008a; Rooke \& Bergström 2007; Tsumele, Mlambo \& Sebata 2006). The response of shoots is not necessarily a real response in total plant growth, but is the result of resources being reallocated to rectify browsing-induced shifts in the root : shoot ratio (Teague 1985; Teague \& Walker 1988). Numerous studies have reported negative effects of long-term severe browsing on plant height (Augustine \& McNaughton 2004; Birkett \& Stevens-Wood 2005; Fornara \& Du Toit 2008b; Levick \& Rogers 2008; Noumi et al. 2010). In contrast, very few studies have considered stem size, which has been found to either decrease or increase under long-term severe browsing (Augustine \& McNaughton 2004; Dharani et al. 2008; Noumi et al. 2010; Riginos \& Young 2007; Rohner \& Ward 1999; Scogings 1998). The significance of stem size is that it is closely related to plant mass and therefore is likely to reflect the whole plant's response, which is important to understand because whole-plant under-compensation 
may indicate progressive carbon $(\mathrm{C})$ exhaustion and reduced life expectancy (Hester et al. 2006; Nickless, Scholes \& Archibald 2010; Teague 1988).

Spatial and temporal variations in resource availability are important considerations for understanding plant responses to browsing in Africa's savannas (Sankaran, Ratnam \& Hanan 2008). Savannas are seasonal systems characterised by alternating wet and dry seasons of several months each (Kutsch et al. 2008). Water, and hence nutrients, are most available when elevated soil water drives a pulse of nitrogen (N) mineralisation at the start of the wet season (Jacobs et al. 2007; Scholes, Bond \& Eckhardt 2003). Plant growth is therefore confined to the wet season, but is intermittent because of fluctuating resources that limit growth (Williams et al. 2009). In addition to the temporal variation in resource availability, soil fertility varies spatially from sandy soils to clay-rich soils (Hopcraft, Olff \& Sinclair 2009; Scholes et al. 2003). Conventionally, clay-rich savannas are described as being dominated by 'fine-leaved', spiny, tannin-poor, 'palatable' species, whilst clay-poor savannas are said to be dominated by 'broad-leaved', spineless, tannin-rich, 'unpalatable' species (Kutsch et al. 2008; Scholes 1997). Whether mineral $\mathrm{N}$ is always available in the soil (e.g. clay) or is only available when mineralised by soil organisms, water is needed in both cases to mobilise $\mathrm{N}$ for plants (Jacobs et al. 2007; Williams et al. 2009 and references therein). Plants on both soil types could therefore experience temporary periods of 'rich' resource availability in otherwise 'poor' resource conditions, regardless of whether the soils are perceived to be 'fertile' or not (Jacobs et al. 2007). Hence, it is distinctly feasible that 'fine-leaved' and 'broad-leaved' species, which may be intuitively expected to respond differently to each other, may not differ consistently in their responses.

The primary aim of this paper is to report stem girth growth of six ubiquitous woody species in the Acacia nigrescens Combretum apiculatum savanna of the Kruger National Park during the period 2006-2010. In doing so, the paper aims to explore the question: what effect does browsing and season have on woody stem growth? The following null hypothesis was formulated to guide the analysis: browsing does not reduce stem growth in either the wet season or the dry season. The hypothesis was tested by analysing data compiled from dendrometer observations between the fourth and eighth years following the establishment of the Nkuhlu Largescale Long-term Exclusion Experiment (NLLEE). Hence, it was not only possible to collect valuable data on woody stem growth in a semi-arid savanna, but other unanswered questions fundamental to understanding the functioning of savannas could be addressed in an experimental context. Because contrasting soils existed at either end of the catena on which the experiment was situated, it was also possible to consider potential influences of soil types on woody stem growth. Furthermore, because the suite of species used in the study comprised both 'fine-leaved' and 'broad-leaved' species, it was possible to explore whether or not patterns of stem growth reflected traditionally recognised functional groups of woody species. This paper represents the first documentation of data on stem growth rates of a suite of woody species in relation to large mammal herbivores in African savannas.

\section{Methods Study area}

The NLLEE $\left(24^{\circ} 58^{\prime} \mathrm{S}, 31^{\circ} 46^{\prime} \mathrm{E}\right)$ is adjacent to the Sabie River, Kruger National Park, South Africa (O'Keefe \& Alard 2002). The climate is semi-arid subtropical with two broadly distinct seasons: a hot, occasionally wet, growth season (OctoberApril) and a warm, dry, non-growing season (Williams et al. 2009). Mean annual rainfall (MAR) at Skukuza, $30 \mathrm{~km}$ west of $\mathrm{Nkuhlu}$, is approximately $550 \mathrm{~mm}$. Average daily temperatures at Skukuza are $15.7{ }^{\circ} \mathrm{C}$ in June and $26.6{ }^{\circ} \mathrm{C}$ in January (http:/ / www.sanparks.org/parks/kruger/conservation/scientific/ weather). Average minimum temperature in June is $5.7{ }^{\circ} \mathrm{C}$ and average maximum temperature in January is $32.6{ }^{\circ} \mathrm{C}$. The topography is an undulating landscape, $200 \mathrm{~m}-230 \mathrm{~m}$ above mean sea level, derived from granite and covering the sequence of terrain morphology from footslope to crest. The crests and middle slopes are characterised by shallow, sandy, coarse soil overlying rock, whilst the footslopes below the seepline are characterised by deep, sodic, duplex soil, which is a typical pattern on catenas in granite-derived, semi-arid landscapes (Grant \& Scholes 2006; Khomo \& Rogers 2005). Sodic soils in the study area comprise shallow $(<15 \mathrm{~cm})$ sand overlying impermeable clay and have high $\mathrm{pH}(>8.5)$ and reduced hydraulic conductivity (Grant \& Scholes 2006; Khomo \& Rogers 2005; Tarasoff, Mallory-Smith $\&$ Ball 2007). Sodic soils are therefore regarded as stressful environments for vegetation, which is sparse, but regarded as more attractive than crest vegetation to large herbivores, especially grazers and mixed feeders (Levick \& Rogers 2008; Tarasoff et al. 2007). It is unclear if the attractiveness of sodic patches to herbivores is because the vegetation is inherently more nutritious, or because it offers other attractions such as predator vigilance, water, dietary salts or anti-acidosis minerals (Abrahamson 1999; Khomo \& Rogers 2005). Nevertheless, trampling, excretion and defoliation are thought to maintain the vegetation in a nutritious vegetative state (Grant \& Scholes 2006).

Plant communities were described by Siebert and Eckhardt (2008). Abundant woody species (nomenclature follows Schmidt, Lötter \& McCleland 2007) include Acacia grandicornuta, Euclea divinorum, Spirostachys africana and Pappea capensis on the sodic footslopes and Dichrostachys cinerea, Acacia exuvialis, Acacia nigrescens, Combretum apiculatum, Combretum hereroense, Combretum zeyheri, Grewia flavescens, Grewia bicolor, Lannea schweinfurthii Rhigozum zambesiacum, Ormocarpum trichocarpum and Philenoptera violacea on the sandy middle slopes and crests. Most of the woody species are deciduous and shorter than $10 \mathrm{~m}$. Common mammal herbivores (nomenclature follows Skinner \& Chimimba 2005) include impala (Aepyceros melampus), African elephant (Loxodonta africana), hippo (Hippopotamus amphibius), black rhino (Diceros bicornis), blue wildebeest (Connochaetes taurinus), Cape buffalo (Syncerus caffer), plains 
zebra (Equus quagga), greater kudu (Tragelaphus strepsiceros), steenbok (Raphicerus campestris), giraffe (Giraffa camelopardalis) and scrub hare (Lepus saxatilis). Elephant, impala, kudu, giraffe, black rhino and steenbok include substantial woody vegetation in their diets. Elephant density in the study area fluctuates, but has been estimated to be $0.5 \mathrm{~km}^{-2}-2.0 \mathrm{~km}^{-2}$, which is considered to be high (Grant et al. 2008). A breeding herd of 30-40 impala, several impala bachelors, two black rhino and an unknown number of steenbok reside in the study area, whilst low numbers of giraffe and kudu occur occasionally.

\section{Design and procedure}

Experimental exclusion plots were established in 2002 on the premise that exclusion of large herbivores (especially elephants) would allow their effects on components of the ecosystem to be determined (O'Keefe \& Alard 2002). The experiment covers 139 ha and is intended to be maintained for at least 25 years. Owing to the scale of the experiment, it was not practical to replicate treatments (Jonsson et al. 2010; Levick \& Rogers 2008). One exclusion plot (approximately $70 \mathrm{ha}$ ) excludes all herbivores the size of hares and larger, whilst a second exclusion plot (approximately 44 ha) excludes elephants (and also giraffe due to their height), but not other herbivores (O'Keefe \& Alard 2002). The two exclusion plots are separated by a control area (approximately $25 \mathrm{ha}$ ) open to all large herbivores. Therefore, if excluding either elephants or all large herbivores shows similar responses then it can be inferred that the main source of the effect is elephants (Engdahl 2008; Jonsson et al. 2010). If excluding elephants shows a different response to excluding all large herbivores then it can be inferred that the main source of the effect is not elephants.

Manual dendrometers (Agricultural Electronics Corporation, Tucson, USA) were used for the study. Each dendrometer consisted of a metal band $(3 \mathrm{~mm} \times 0.75 \mathrm{~mm})$ of user-defined length attached to a spring-loaded vernier gauge graduated to $0.1 \mathrm{~mm}$ precision. The dendrometers were attached at a height of $20 \mathrm{~cm}$ above ground on the main stems of 244 randomly selected individuals of three 'fine-leaved' species (A. exuvialis, A. grandicornuta, D. cinerea) and three 'broadleaved' species (C. apiculatum, E. divinorum, G. flavescens) in both exclusion plots as well as in the control area. The fitted trees were in areas protected from fire. The selected species were amongst the most abundant woody species in the study area. Several extra dendrometers were deployed in the control area compared to the exclusion plots to allow for anticipated losses over the anticipated years of monitoring (e.g. by animals uprooting or felling plants, or damaging the instruments by chewing or rubbing on them). A GPS was used to randomly locate sites in a grid of $30 \mathrm{~m} \times 30 \mathrm{~m}$ cells. An anomalous basaltic outcrop covering approximately $15 \%$ of the partial exclusion plot was excluded from sampling. One tree of each study species was located in each grid cell on condition that it was, (1) closest to the grid-cell centre, (2) taller than $2 \mathrm{~m}$ and (3) neither obviously stressed by disease, disturbance or neighbours, nor obviously growing in a nutrient-enriched patch such as a termite mound or hollow.
The minimum height of selected G. flavescens plants was $1.5 \mathrm{~m}$ because it seldom grew taller than $2 \mathrm{~m}$. If any condition was not met for the closest tree, then the next closest tree that met the conditions was sampled. Girth $(\mathrm{mm})$ of the dominant stem was measured before positioning a band on the stem. The vernier gauges were initially set at approximately $5 \mathrm{~mm}$ to allow for possible shrinkages to be recorded and were reset whenever they reached $>25 \mathrm{~mm}$. The dendrometers were observed (to $0.1 \mathrm{~mm}$ ) at intervals of one-three months, depending on logistical constraints, from September 2006 to February 2010. Total rainfall at Skukuza in 2006/2007 and $2007 / 2008$ was below MAR, but in 2008/2009 and 2009/2010 it was above MAR (Figure 1). Furthermore, monthly rainfall during the second half of three of the wet seasons included in the study period was below the long-term average for each month. Not all dendrometers were operational for the whole study period because of failure or damage. Increments between successive observations were calculated for the operational period of each dendrometer.

To test the interaction between plot and season, the wet season was simply defined as the six months from November to April, whilst the dry season comprised the remaining six months. Monthly increments per dendrometer were calculated by dividing each individual increment by the number of months over which the increment had occurred. Average monthly increments (AMIs) per season were then calculated across years for each dendrometer, giving a wetseason AMI $\left(\mathrm{AMI}_{\text {wet }}\right)$ and a dry-season AMI (AMI ${ }_{\text {dry }}$ ) for each dendrometer. Net AMI (NAMI) for each dendrometer was calculated as the sum of $\mathrm{AMI}_{\text {wet }}$ and $\mathrm{AMI}_{\mathrm{dry}}$. Each species' data were analysed separately to test effects within species using SYSTAT 10 (SPSS 2000). Two-factor ANOVA was used to test the interaction effect of plot and season on either $\log _{10}(A M I+1)$ or $\sqrt{ }(A M I+1)$, whilst one-factor ANOVA was used to test the effect of plot on either $\log _{10}$ $(\mathrm{NAMI}+1)$ or $\sqrt{(\mathrm{NAMI}}+1)$, whichever transformation normalised the distribution of a species' data. Individual plants were assumed as replicates within each treatment. Therefore, pseudo-replication constrained the analyses and estimates of model parameters were viewed with caution (Underwood 1997:245). Initial stem girth was included as a covariate in all analyses, but was dropped from the model if it had no effect. In all analyses, significant effects were declared when $p<0.05$, but possible trends were not ignored when $0.05<p<0.10$ indicated marginal significance. Finally, to facilitate consideration of differences amongst functional groups of species, estimates of average annual growth per species were obtained by calculating average annual girth growth from mean NAMI $\times 12$ and average annual radial growth though division of girth growth by $\pi / 2$. Because the dendrometers used in this study are intended to be observed for several more years, a thorough quantitative analysis of annual growth rates will be appropriate after a longer series of annual data has been completed.

\section{Results}

Mean initial girth of each plant varied amongst the study species when it was fitted with a dendrometer (Figure 2). Initial girth was largest for A. grandicornuta, followed 


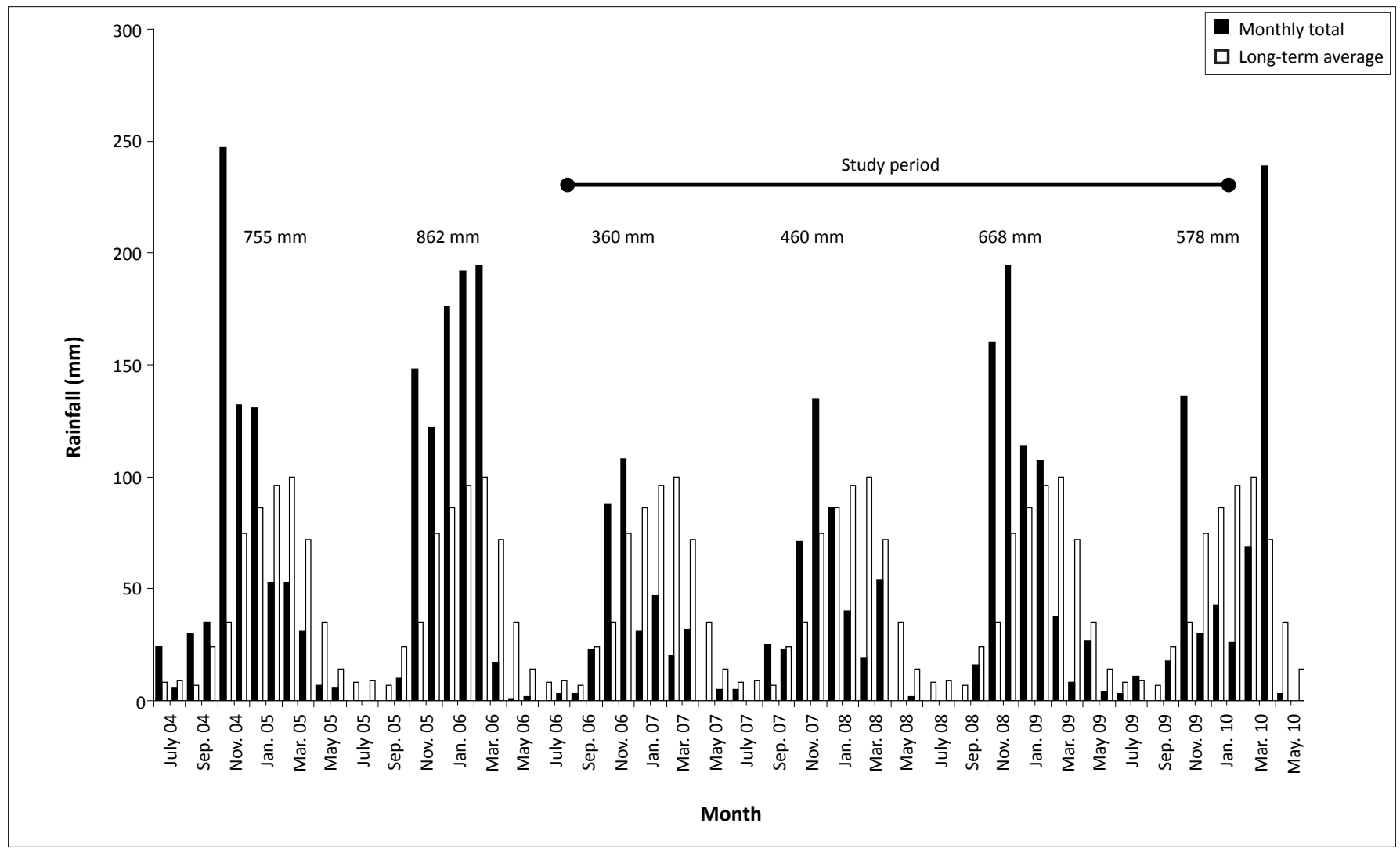

FIGURE 1: Monthly rainfall at Skukuza for the duration of the study and two years prior to the study. For comparison, long-term average monthly rainfall is also shown. Total annual rainfall for each year (July to June) is indicated above the bars.

by C. apiculatum, but was smallest for G. flavescens. Initial girth had no effect as a covariate in any of the analyses $(p>0.05)$. All species experienced significant effects of season on AMI $(p<0.05)$, whilst marginally significant interactions between plot and season affected $D$. cinerea $\left(F_{2,72}=2.92\right.$; $p=0.060)$ and $G$. flavescens $\left(F_{2,72}=2.58 ; p=0.082\right)$. Wet-season AMI of D. cinerea and dry-season AMI of $G$. flavescens tended to be reduced by exclusion of all large herbivores (Figure 3). Reduction of the analysis to a simple comparison of $\mathrm{AMI}_{\mathrm{dry}}$ and $\mathrm{AMI}_{\text {wet }}$ within species revealed that, whilst $\mathrm{AMI}_{\text {dry }}$ was zero for $D$. cinerea, G. flavescens and C. apiculatum, it was negative for A. exuvialis and positive for A. grandicornuta and E. divinorum (Figure 4). When NAMI was tested per species, D. cinerea was affected only marginally by browser exclusion $\left(F_{2,36}=2.61\right.$; $p=0.087)$. Mean NAMI of $D$. cinerea was $0.97 \mathrm{~mm}(\mathrm{SEM}=0.226)$, $1.26 \mathrm{~mm}(\mathrm{SEM}=0.236)$ and $1.77 \mathrm{~mm}(\mathrm{SEM}=0.273)$ in the complete exclusion, partial exclusion and control plots, respectively.

Average annual girth growth rates of the measured trees were estimated to be $10.6 \mathrm{~mm}, 8.2 \mathrm{~mm}$ and $8.0 \mathrm{~mm}$ for G. flavescens, D. cinerea and C. apiculatum, respectively, and $6.1 \mathrm{~mm}, 6.0 \mathrm{~mm}$ and $5.8 \mathrm{~mm}$ for A. exuvialis, A. grandicornuta and $E$. divinorum, respectively. Correcting these estimates to account for differences in initial girth amongst the species gives values of $0.09 \mathrm{~mm} \mathrm{~mm}^{-1}, 0.05 \mathrm{~mm} \mathrm{~mm}^{-1}$,

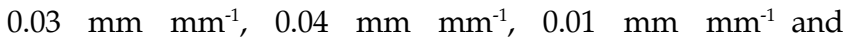
$0.03 \mathrm{~mm} \mathrm{~mm}^{-1}$, respectively. Narrow-stemmed species (G. flavescens, $D$. cinerea and $A$. exuvialis) were relatively faster growing than wide-stemmed species (E.divinorum,C.apiculatum and $A$. grandicornuta). Corresponding average annual radial growth rates (uncorrected) of the measured treeswere $1.68 \mathrm{~mm}$, $1.31 \mathrm{~mm}, 1.27 \mathrm{~mm}, 0.96 \mathrm{~mm}, 0.95 \mathrm{~mm}$ and $0.92 \mathrm{~mm}$. Therefore, the slower growing trees included in the study increased girth by approximately $5.9 \mathrm{~mm}$ per year, whilst the faster growing trees increased girth by approximately $8.9 \mathrm{~mm}$ per year, corresponding to approximately $0.94 \mathrm{~mm}$ and $1.42 \mathrm{~mm}$ radial growth per year.

\section{Discussion and conclusion}

The null hypothesis that browsing does not reduce the growth of woody stem girths in either the wet season or the dry season was not rejected for the particular suite of species observed over the duration of the study at the NLLEE. Because excluding only elephants had no effect compared to the control treatment, it can be inferred that any trends associated with exclusion were not related to elephants. The most intuitive reason for not observing effects of browser exclusion is that the timing and duration of the study were not long enough to detect differences in semi-arid savannas, even though several studies across a wide range of rainfall (and soils) have shown otherwise (e.g. Augustine \& McNaughton 2004; Dharani et al. 2008; Riginos \& Young 2007; Sharam, Sinclair \& Turkington 2006). On the other hand, no difference in stem girth growth suggests a positive effect of browsing on plant growth rate leading to compensation (Renton, Thornby \& Hanan 2007).

However, the results did suggest that certain trends existed amongst the species during the study period, which are 


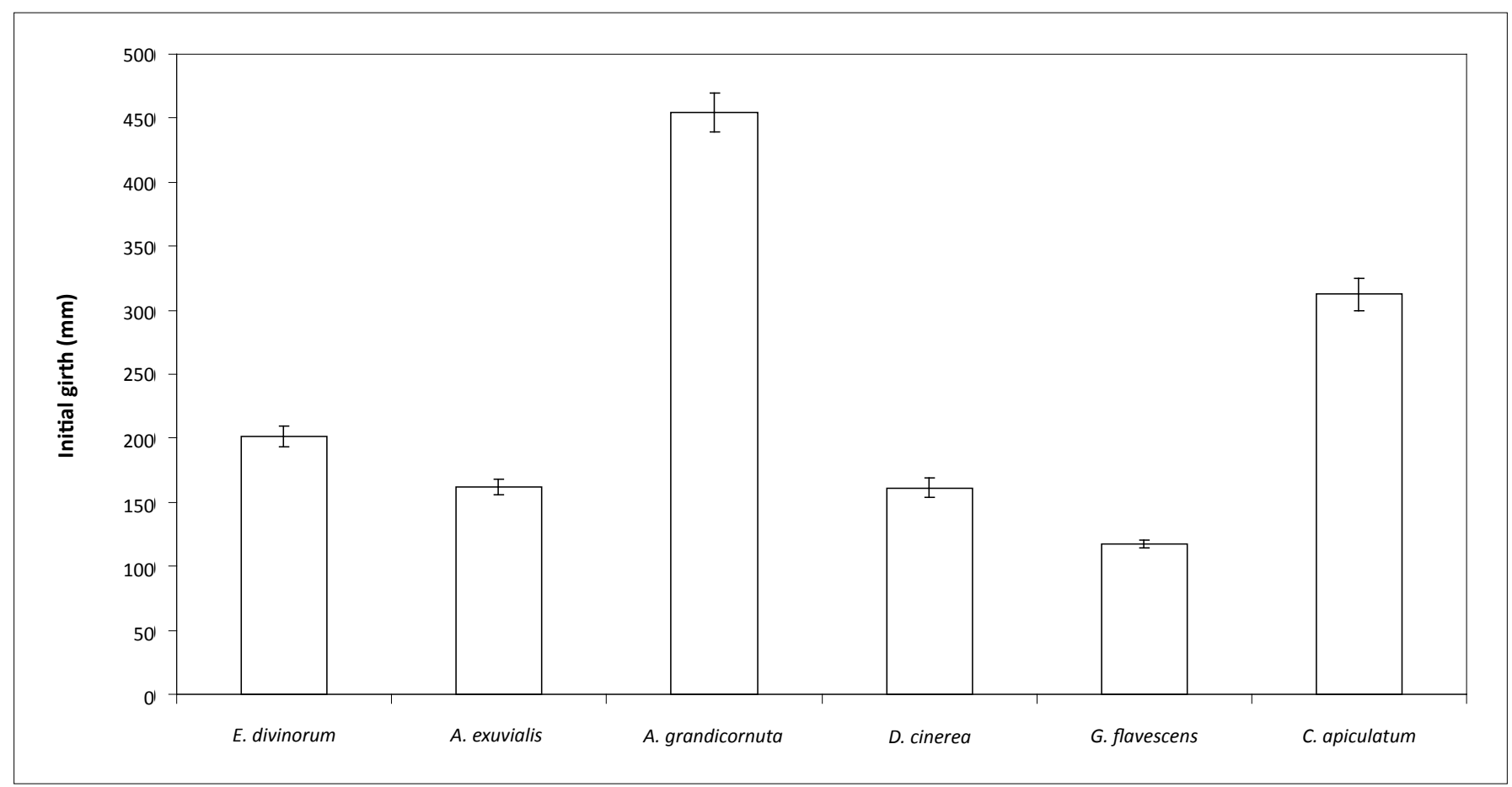

FIGURE 2: Mean initial girth ( $\mathrm{mm}$ ) of stems fitted with dendrometers at the Nkuhlu exclusion experiment. Error bars are standard errors of the means (from left to right, $n=39,41,41,39,39$ and 44). Species from left to right are: Euclea divinorum, Acacia exuvialis, Acacia grandicornuta, Dichrostachys cinerea, Grewia flavescens and Combretum apiculatum.

worth monitoring for some years to come as they may develop into real effects over a longer time period. For example, after several more years it is expected that negative effects of complete exclusion of large herbivores will become more pronounced (Scogings et al. in press). The trends in the data also suggest partial exclusion may have negative effects on some species, for example, $D$. cinerea. The observed trends in D. cinerea complement observed changes in height of woody plants in the first five years of browser exclusion (Scogings et al. in press). Both the dendrometer and height data showed $D$. cinerea responding more strongly than other species to browser exclusion, where exclusion of all large herbivores increased height but tended to decrease stem girth, relative to no or partial exclusion. Increasing height growth and decreasing girth may reflect increased competition for light, as is typically seen when shaded plants grow tall and thin ( $\mathrm{O}^{\prime}$ Connor 1995). The results suggest stem radial growth of some fast-growing species is more prone to reduction by browser exclusion than the growth of other species, potentially as an indirect effect through increased competition (Scogings et al. in press). After a few more years, the data will also give insights into mortality rates of each species monitored, as either direct or indirect effects of browser exclusion. The results suggested that exclusion of large herbivores may lead to increasingly adverse effects on growth rates of some species; therefore exclusion may influence drought related mortality in the long term because fast-growing plants are prone to drought stress (Pollastrini et al. 2010).

Dharani et al. (2008) measured Acacia xanthophloea trees of similar size to the ones measured at the NLLEE. Growth was faster with than without browsing, which corroborates some of the trends observed amongst species studied at the
NLLEE. Riginos and Young (2007) found faster stem growth in Acacia drepanolobium with than without browsing, possibly due to elephants reducing competitive effects of grasses. In contrast, other studies have found reduced growth for several species under browsing compared to exclusion (Augustine \& McNaughton 2004; Scogings 1998). The overall stem growth rates observed at the NLLEE appear to be comparable to those observed in other studies. Dharani et al. (2008) observed stem growth rates higher than the ones at the NLLEE, but Scogings (1998) observed growth rates of six species that were generally lower than similar size trees at the NLLEE. Stem growth of Grewia tenax plants over three years following browser exclusion was found by Augustine and McNaughton (2004) to be similar to that of G. flavescens plants of similar height at the NLLEE, but Acacia mellifera and Acacia etbaica had much higher growth rates compared to any of the species studied at the NLLEE. None of the aforementioned studies observed either zero or negative rates. Further research is needed before generalisations in stem growth amongst species and sites can be postulated.

Because of the complexity of savanna ecosystems, efforts to understand their functioning necessitate simplification by means of models. Much is often generalised about the ecology of woody plants in savannas on the basis of functional groups that have been traditionally adopted to facilitate such efforts (e.g. see Staver et al. 2009), although no clear definitions of the traditionally used terms exist in a savanna context. The leaf-size dichotomy usually forms the basis for further generalisations to be made about other aspects of woody species, such as the 'palatability' of woody plants in savannas. 'Fine-leaved' species are perceived to be 'palatable' because they are deemed to be poorly endowed with C-based secondary metabolites (e.g. condensed tannins) 


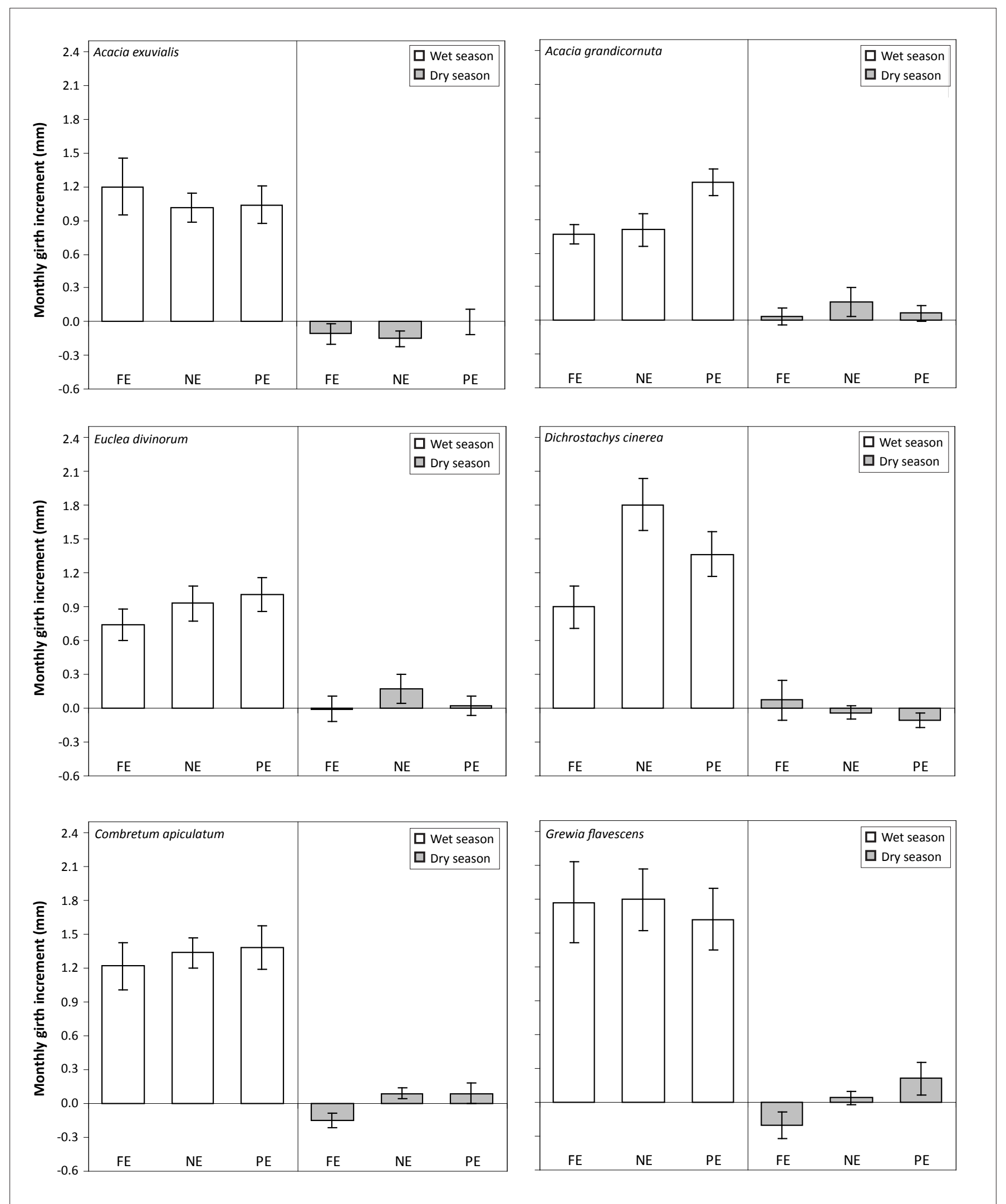

FIGURE 3: Mean monthly increment in stem girth of six abundant woody species in the wet and dry seasons at the Nkuhlu exclusion experiment, 2006-2010. Error bars are standard errors of the means (for columns FE, NE and PE, $n=13,15$ and 14 for Acacia exuvialis; 12,15 and 12 for Acacia grandicornuta, Euclea divinorum, Dichrostachys cinerea and Combretum apiculatum; and 12, 18 and 12 for Grewia flavescens). FE, exclusion of all large herbivores greater than hares; NE, control (no exclusion); PE, exclusion of elephants and giraffe only. 


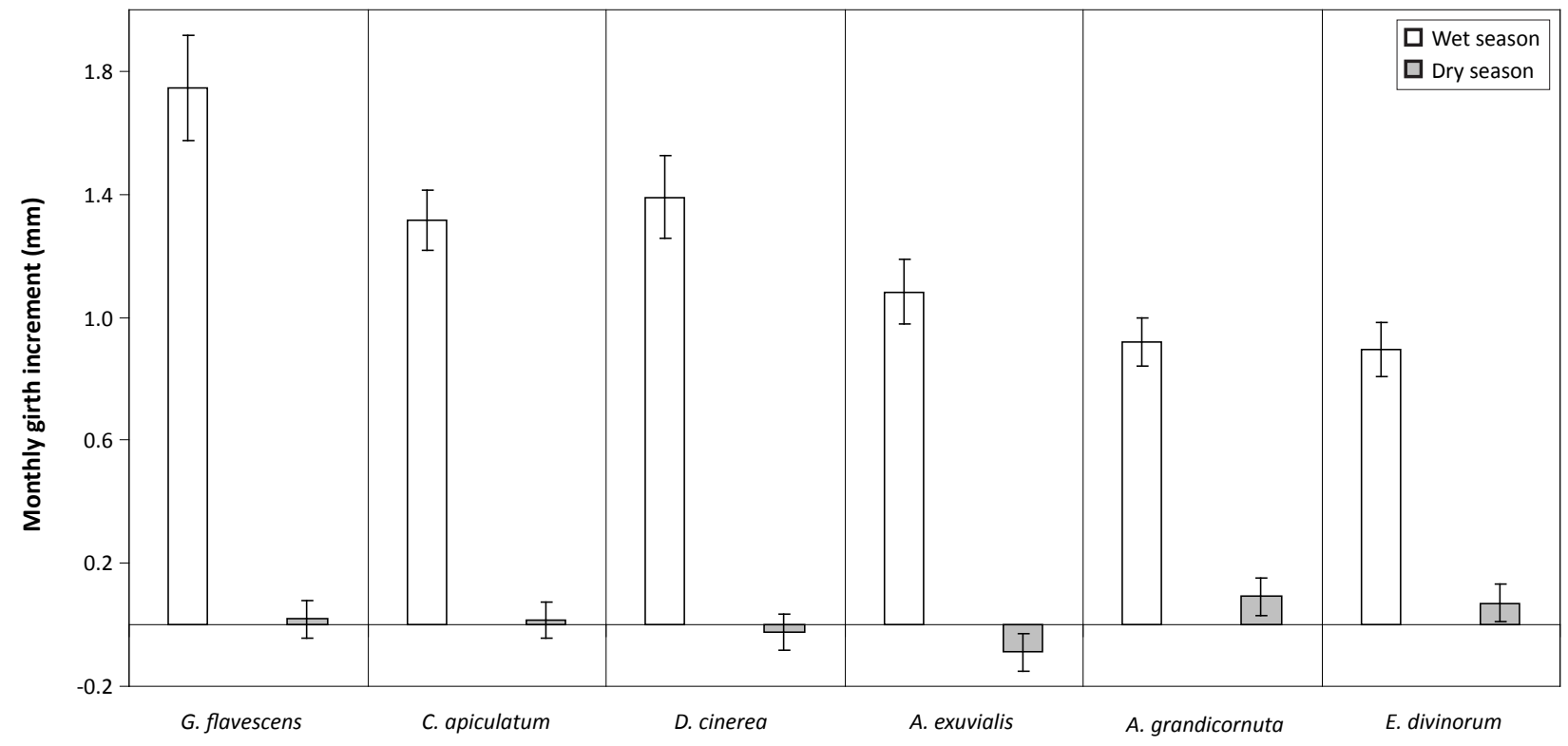

FIGURE 4: Mean monthly increment in stem girth of six abundant woody species in the wet and dry seasons across all treatments at the Nkuhlu exclusion experiment, 2006-2010. Species from left to right are: Grewia flavescens, Combretum apiculatum, Dichrostachys cinerea, Acacia grandicornuta, Acacia exuvialis and Euclea divinorum. Error bars are standard errors of the means ( $n=44$ for $G$. flavescens, 39 for $D$. cinerea, 39 for $C$. apiculatum, 42 for $A$. exuvialis, 41 for $A$. grandicornuta, and 39 for $E$. divinorum).

in favour of thorns or spines (Kutsch et al. 2008; Scholes 1997). The perception derives from an assumed trade-off between growth and chemical defences (Herms \& Mattson 1992). The observation that many 'fine-leaved' woody species are, (1) involved in bush encroachment and (2) display stimulated shoot growth in response to browsing, may be regarded as supporting the ultimate view that 'fine-leaved', spiny species are 'palatable', fast-growing and tolerant of severe browsing, compared to 'broad-leaved' species (Moleele \& Perkins 1998; Sweet \& Mphinyane 1986). The validity of such generalisations has not been tested.

Although the dendrometer study was not designed to test differences amongst functional groups of species, growth rates did not obviously correspond with leaf type because 'fine-leaved' species did not grow faster than 'broadleaved' species. Furthermore, analysis of low molecular weight phenolic compounds known to influence herbivores did not show clear distinction between 'fine-leaved' and 'broad-leaved' species at the NLLEE (Hattas et al. in press). Acacia exuvialis, in particular, is an example of 'fine-leaved' species that are well endowed with both C-based secondary metabolites and long thorns. However, growth rates did appear to be related to soil type and slope position. Acacia grandicornuta and E. divinorum, which were abundant on the clay-rich sodic soils of the footslopes, maintained slightly positive growth in the dry season, whilst species on the sandy crests either did not grow or shrank in the dry season, which is likely related to differences in the timing of water availability across the catena (Jacobs et al. 2007).

In conclusion, this study provides evidence that stem growth of woody plants in African savannas is strongly seasonal, but the effects of large herbivores on woody plant growth remains unclear and requires further research. The results also suggest that catenal position and associated differences in soil type and hydrology generally influences stem growth. Not all species within the broad functional groups of woody plants traditionally recognised in African savannas show the same stem growth patterns. Long-term monitoring of dendrometers fitted to a variety of species in manipulative situations would provide much-needed insights into growth dynamics of woody plants, which could help managers of conservation areas to identify species prone to high risk of extirpation.

\section{Acknowledgements}

The Zululand/Sweden Kruger Browse Project was funded by the National Research Foundation, University of Zululand, Agricultural Research Council, Swedish Research Council and Swedish International Development Agency. I would also like to acknowledge Tuulikki Rooke, Dawood Hattas, Luthando Dziba and Alpheus Zobolo for their enthusiastic contributions to development and implementation of the project, as well as Thandeka Mamashela, Patricia Shabangu, Ntuthuko Mkhize, Julius Tjelele, Basanda Nondlazi, Gilbert Pule, Sicelo Dludla, Andries Malate, Ngcebo Ngcobo, Frederik Engdahl and Elin Gunve for their help in the field. Scientific Services personnel, especially Adolf Manganyi, Nokukhanya Mpanza and Noel Nzima, also provided critical support for the fieldwork. Finally, I would like to acknowledge the assistance provided by the two anonymous reviewers, who contributed to improving the manuscript.

\section{References}

Abrahamson, P.W., 1999, 'The chemistry and mineralogy of three savanna lick soils', Journal of Chemical Ecology 25, 2215-2228. doi:10.1023/A:1020861505138

Augustine, D.J. \& McNaughton, S.J., 2004, 'Regulation of shrub dynamics by native browsing ungulates on East African rangeland', Journal of Applied Ecology 41, 45-58. doi:10.1111/j.1365-2664.2004.00864.x 
Baxter, P.W.J. \& Getz, W.M., 2005, 'A model-framed evaluation of elephant effects on tree and fire dynamics in African savannas', Ecological Applications 15 1331-1341. doi:10.1890/02-5382

Bergström, R., Skarpe, C. \& Danell, K., 2000, 'Plant response and herbivory following simulated browsing and stem cutting of Combretum apiculatum', Journal of Vegetation Science 11, 409-414. doi:10.2307/3236633

Birkett, A. \& Stevens-Wood, B., 2005, 'Effect of low rainfall and browsing by large herbivores on an enclosed savannah habitat in Kenya', African Journal of Ecology 43, 123-130. doi:10.1111/j.1365-2028.2005.00555.x

Dharani, N., Kinyamario, J.I., Wagacha, P.W. \& Rodrigues, A.J., 2008, 'Browsing impact of large herbivores on Acacia xanthophloea Benth in Lake Nakuru Nationa Park, Kenya', African Journal of Ecology 47, 184-191. doi:10.1111/j.1365 2028.2008.00954.x

Engdahl, F., 2008, 'Herbivory on woody plants and induced responses in two similar species of Acacia in the Kruger National Park, South Africa', MSc thesis, Department of Wildlife, Fish and Environmental Studies, Swedish University of Agricultural Sciences.

Fornara, D.A. \& Du Toit, J.T., 2007, 'Browsing lawns? Responses of Acacia nigrescens to ungulate browsing in an African savanna', Ecology 88, 200-209. doi:10.1890/00129658(2007)88[200:BLROAN]2.0.CO;2

Fornara, D.A. \& Du Toit, J.T., 2008a, 'Responses of woody saplings exposed to chronic mammalian herbivory in an African savanna', Ecoscience 15, 129-135. doi:10.2980/1195-6860(2008)15[129:ROWSET]2.0.CO;2

Fornara, D.A. \& Du Toit, J.T., 2008b, 'Community-level interactions between ungulate browsers and woody plants in an African savanna dominated by palatablespinescent Acacia trees', Journal of Arid Environments 72, 534-545. doi:10.1016/j. jaridenv.2007.07.010

Grant, C.C., Bengis, R., Balfour, D. \& Peel, M., 2008, 'Controlling the distribution of elephants', in R.J. Scholes \& K.G. Mennell (eds.), Elephant management: A scientific assessment for South Africa, pp. 329-369, Wits University Press, Johannesburg.

Grant, C.C. \& Scholes, M.C., 2006, 'The importance of nutrient hotspots in the conservation and management of large wild mammalian herbivores in semi-arid savannas', Biological Conservation 130, 426-437. doi:10.1016/j. semi-arid savannas'

Hattas, D., Hjältén, J., Julkunen-Tiitto, R., Scogings, P.F. \& Rooke, T., in press, 'Differential phenolic profiles in six African savanna woody species in relation to antiherbivore defense', Phytochemistry.

Herms, D.A. \& Mattson, W.J., 1992, 'The dilemma of plants: To grow or defend', Quarterly Review of Biology 67, 283-335. doi:10.1086/417659

Hester, A.J., Bergman, M., Iason, G.R. \& Moen, J., 2006, 'Impacts of large herbivores on plant community structure and dynamics', in K. Danell, R. Bergström, P. Duncan \& J. Pastor (eds.), Large herbivore ecology, ecosystem dynamics and conservation, pp. 97-141. Cambridge University Press, Cambridge. doi:10.1017/ CBO9780511617461.006

Hopcraft, J.G.C., Olff, H. \& Sinclair, A.R.E., 2009, 'Herbivores, resources and risks: Alternating regulation along primary environmental gradients in savannas', Trends in Ecology \& Evolution 25, 119-128. doi:10.1016/j.tree.2009.08.001

Hrabar, H., Hattas, D. \& Du Toit, J.T., 2009, 'Differential effects of defoliation by mopane caterpillars and pruning by African elephants on the regrowth of Colophospermum mopane foliage', Journal of Tropical Ecology 25, 301-309. Colophospermum mopane foliage

Jacobs, S.M., Bechtold, J.S., Biggs, H.C., Grimm, N.B., Lorentz, S., McClain, M.E. et al., 2007, 'Nutrient vectors and riparian processing: A review with special reference to African semiarid savanna ecosystems', Ecosystems 10, 1231-1249. doi:10.1007/ s10021-007-9092-1

Jonsson, M., Bell, D., Hjältén, J., Rooke, T. \& Scogings, P.F., 2010, ‘Do mammalian herbivores influence invertebrate communities via changes in the vegetation? Results from a preliminary survey in Kruger National Park, South Africa', African Journal of Range \& Forage Science 27, 39-44.

Khomo, L.M. \& Rogers, K.H., 2005, 'Proposed mechanism for the origin of sodic patches in Kruger National Park, South Africa', African Journal of Ecology 43, 29-34. doi:10.1111/j.1365-2028.2004.00532.x

Kutsch, W.L., Hanan, N., Scholes, R.J., McHugh, I., Kubheka, W., Eckhardt, H. et al. 2008, 'Response of carbon fluxes to water relations in a savanna ecosystem in

Levick, S. \& Rogers, K.H., 2008, 'Patch and species specific responses of savanna woody vegetation to browser exclusion', Biological Conservation 141, 489-498.

Makhabu, S.W., Skarpe, C. \& Hytteborn, H., 2006, 'Elephant impact on shoo distribution on trees and on rebrowsing by smaller browsers', Acta Oecologica 30 136-146. doi:10.1016/j.actao.2006.02.005

Moleele, N.M. \& Perkins, J.S., 1998, 'Encroaching woody species and boreholes: Is cattle density the main driving factor in the Olifants Drift communal grazing lands, south-eastern Botswana', Journal of Arid Environments 40, 245-253. doi:10.1006/ jare.1998.0451

Nickless, A., Scholes, R.J. \& Archibald, S., 2010, 'Calculating the variance and prediction intervals for estimates obtained from allometric relationships', paper presented at the 3rd Biennial CSIR Conference, Pretoria, 30 August - 01 September.

Noumi, Z., Touzard, B., Michalet, R. \& Chaieb, M., 2010, 'The effects of browsing on the structure of Acacia tortilis (Forssk.) Hayne ssp. raddiana (Savi) Brenan along a gradient of water availability in arid zones of Tunisia', Journal of Arid Environments $74,625-631$.
O'Connor, T.G., 1995, 'Acacia karroo invasion of grassland: Environmental and biotic effects influencing seedling emergence and establishment', Oecologia 103, 214-223. doi:10.1007/BF00329083

O'Keefe, T. \& Alard, G., 2002, Effects of herbivores and fire on riparian and upland savanna ecosystems: Field operations manual for herbivore and fire exclosures on the Sabie and Letaba Rivers in the Kruger National Park, South African National Parks, Skukuza.

Pollastrini, M., Desotgiu, R., Cascio, C., Bussotti, F., Cherubini, P., Saurer, M. et al., 2010, 'Growth and physiological responses to ozone and mild drought stress of tree species with different ecological requirements', Trees 24, 695-704. doi:10.1007/s00468-010-0439-4

Renton, M., Thornby, D. \& Hanan, J., 2007, 'Canonical modelling: An approach for intermediate-level simulation of carbon allocation in functional-structural plan models', in J. Vos, L.F.M. Marcelis, P.H.B de Visser, P.C. Struik \& J.B. Evers (eds.), Functional-structural plant modelling in crop production, pp. 151-164, Springer, Dordrecht.

Riginos, C. \& Young, T.P., 2007, 'Positive and negative effects of grass, cattle, and wild herbivores on Acacia saplings in an East African savanna', Oecologia 153, 985-995. doi:10.1007/s00442-007-0799-7, PMid:17661089

Rohner, C. \& Ward, D., 1999, 'Large mammalian herbivores and the conservation of arid Acacia stands in the Middle-East', Conservation Biology 13, 1162-1171. doi:10.1046/j.1523-1739.1999.97300.x

Rooke, T. \& Bergström, R., 2007, 'Growth, chemical responses and herbivory after simulated leaf browsing in Combretum apiculatum', Plant Ecology 189, 201-212. doi:10.1007/s11258-006-9177-5

Sankaran, M., Ratnam, J. \& Hanan, N., 2008, 'Woody cover in African savannas: The role of resources, fire and herbivory', Global Ecology \& Biogeography 17, 236-245.

Schmidt, E., Lötter, M. \& McCleland, W., 2007, Trees and shrubs of Mpumalanga and Kruger National Park, Jacana Media, Johannesburg.

Scholes, R.J., 1997, 'Savanna', in R.M. Cowling, D.M. Richardson \& S.M. Pierce (eds.), Vegetation of southern Africa, pp. 258-277, Cambridge University Press, Cambridge.

Scholes, R.J., Bond, W.J. \& Eckhardt, H.C., 2003, 'Vegetation dynamics in the Kruge ecosystem', in J.T. du Toit, K.H. Rogers \& H.C. Biggs (eds.), The Kruger experience: Ecology and management of savanna heterogeneity, pp. 242-246, Island Press, Washington DC.

Scogings, P.F., 1998, 'Resistance of six savanna woody plant species to browsing by goats in the Eastern Cape Province of South Africa', PhD thesis, Department of Livestock and Pasture Science, University of Fort Hare.

Scogings, P.F., Johansson, T., Hjältén, J. \& Kruger, J., in press, 'Woody vegetation and large herbivores in semi-arid savannas', Austral Ecology.

Sharam, G., Sinclair, A.R.E. \& Turkington, R., 2006, 'Establishment of broad-leaved thickets in Serengeti, Tanzania: The influence of fire, browsers, grass competition, and elephants', Biotropica 38, 599-605. doi:10.1111/j.1744-7429.2006.00195.x

Siebert, F. \& Eckhardt, H.C., 2007, 'The vegetation and floristics of the Nkuhlu exclosures, Kruger National Park', Koedoe 50, 126-144.

Skinner, J.D. \& Chimimba, C.T., 2005, The mammals of the southern African subregion, Cambridge University Press, Cape Town.

SPSS, 2000, SYSTAT 10, SPSS Inc., Chicago.

Staver, A.C., Bond, W.J., Stock, W.D., Van Rensburg, S. \& Waldram, M.S., 2009 'Browsing and fire interact to suppress tree density in an African savanna', Ecological Applications 19, 1909-1919. doi:10.1890/08-1907.1, PMid:19831079

Sweet, R.J. \& Mphinyane, W., 1986, 'Preliminary observations on the ability of goats to control post-burning regrowth in Acacia nigrescens/Combretum apiculatum savanna in Botswana', Journal of the Grassland Society of Southern Africa 3 , 79-84.

Tarasoff, C.S., Mallory-Smith, C.A. \& Ball, D.A., 2007, 'Comparative plant responses of Puccinellia distans and Puccinellia nuttalliana to sodic versus normal soil types', Journal of Arid Environments 70, 403-417. doi:10.1016/j.jaridenv.2007.01.008

Teague, W.R., 1985, 'Leaf growth of Acacia karroo trees in response to frequency and intensity of defoliation' in J.C. Tothill \& J.J. Mott JJ (eds.), Ecology and management of the world's savannas, pp. 220-222, Australian Academy of Science, Canberra, and CAB, Farnham Royal.

Teague, W.R., 1988, 'Effect of the intensity and phenophase of defoliation and water stress on the rate of photosynthesis and the recovery of carbohydrate reserves in Acacia karroo Hayne', Journal of the Grassland Society of Southern Africa 5 , 223-226.

Teague, W.R. \& Walker, B.H., 1988, 'Effect of intensity of defoliation by goats at different phenophases on leaf and shoot growth of Acacia karroo Hayne', Journa of the Grassland Society of Southern Africa 5, 197-206.

Tsumele, J., Mlambo, D. \& Sebata, A., 2006, 'Responses of three Acacia species to simulated herbivory in a semi-arid southern African savanna', African Journal of Ecology 145, 325-327.

Underwood, A.J., 1997, Experiments in ecology, Cambridge University Press, Cambridge.

Williams, C.A., Hanan, N., Scholes, R.J. \& Kutsch, W., 2009, 'Complexity in water and carbon dioxide fluxes following rain pulses in an African savanna', Oecologia 161, 469-480. doi:10.1007/s00442-009-1405-y, PMid:19582479, PMCid:2757614 